This pdf of your paper in Deer and People belongs to the publishers Oxbow Books and it is their copyright.

As author you are licenced to make up to 50 offprints from it, but beyond that you may not publish it on the World Wide Web until three years from publication (December 20I4), unless the site is a limited access intranet (password protected). If you have queries about this please contact the editorial department at Oxbow Books (editorial@ oxbowbooks.com). 


\section{An offprint from \\ Deer and People}

edited by

\section{Karis Baker, Ruth Carden and Richard Madgwick}

Paperback Edition: ISBN 978-I-909686-54-O

Digital Edition: ISBN 978-I-909686-55-7

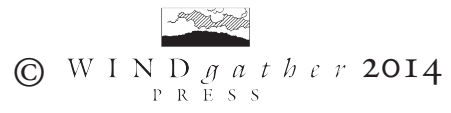

www.oxbowbooks.com 
Windgather Press is an imprint of Oxbow Books

Published in the United Kingdom in 2014 by

OXBOW BOOKS

Io Hythe Bridge Street, Oxford OXI 2EW

and in the United States by

OXBOW BOOKS

908 Darby Road, Havertown, PA 19083

(C) Windgather Press and the individual contributors 2014

Paperback Edition: ISBN 978-I-909686-54-0

Digital Edition: ISBN 978-I-909686-55-7

A CIP record for this book is available from the British Library

All rights reserved. No part of this book may be reproduced or transmitted in any form or by any means, electronic or mechanical including photocopying, recording or by any information storage and retrieval system, without permission from the publisher in writing.

Printed in the United Kingdom by Gutenberg Press, Malta

For a complete list of Windgather titles, please contact:

United Kingdom

Oxbow Books

telephone (01865) 24I249

Fax (or865) 794449

Email: oxbow@oxbowbooks.com

www.oxbowbooks.com
United States of America

Oxbow Books

telephone (800) 79I-9354

Fax (6IO) 853-9I46

Email: queries@casemateacademic.com www.casemateacademic.com/oxbow

Oxbow Books is part of the Casemate group

Front cover: Red deer, photo by R. Carden. Inset, top to bottom: Queen Elizabeth I at a stag hunt, British Library, London/The Bridgeman Art Library; red deer teeth, photo by E. Stephan; Bronze Age scene from Boregtiin Gol, Mongolia, photo by R. Kortum; worked antler and bone, photo by E. Gál.

Back cover: Drawing by J. Cotton 


\section{Contents}

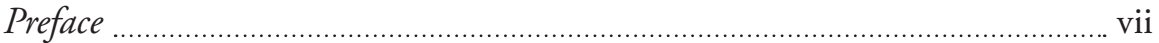

List of Contributors ………………………………………………………… ix

\section{Deer Dispersal and Interactions with Humans}

I. Genetic Analyses of Natural and Anthropogenic Movements ....................... 2 in Deer Allan D. McDevitt and Frank E. Zachos

2. Historic Zoology of the European Fallow Deer, Dama dama dama:

Evidence from biogeography, archaeology and genetics

Marco Masseti and Cristiano Vernesi

3. Human-Deer Interactions in Sardinia

Gabriele Carenti, Elisabetta Grassi, Stefano Masala and Barbara Wilkens

4. Enduring Relationships: Cervids and humans from Late Pleistocene to modern times in the Yukon River basin of the western Subarctic of North America

Carol Gelvin-Reymiller ${ }^{\dagger}$

\section{Cervid Exploitation and Symbolic Significance}

in Prehistoric and Early Historic Periods

5. Hunting, Performance and Incorporation: Human-deer encounter in Late Bronze Age Crete ..................................................................... 48

Kerry Harris

6. Archaeozoology of the Red Deer in the Southern Balkan Peninsula and the Aegean Region during Antiquity: Confronting

bones and paintings

Katerina Trantalidou and Marco Masseti

7. The Italian Neolithic Red Deer: Molino Casarotto 78

Katherine Boyle

8. Evidence for the Variable Exploitation of Cervids at the Early

Bronze Age Site of Kaposújlak-Várdomb

(South Transdanubia, Hungary)

Erika Gál

9. Red Deer Hunting and Exploitation in the Early Neolithic Settlement of Rottenburg-Fröbelweg, South Germany

Elisabeth Stephan 
Io. Red Deer Antlers in Neolithic Britain and their Use in the Construction of Monuments

Fay Worley and Dale Serjeantson

I I. Antler Industry in the Upper Magdalenian from Le Rond du Barry, Polignac, Haute-Loire, France

Delphine Remy and Roger de Bayle des Hermens ${ }^{\dagger}$

I2. Deer (Rangifer tarandus and Cervus elaphus) Remains from the Final Gravettian of the Abri Pataud and their Importance to Humans

Carole Vercoutère, Laurent Crépin, Dorothée G. Drucker, Laurent Chiotti, Dominique Henry-Gambier and Roland Nespoulet

I3. Deer Stones and Rock Art in Mongolia during the Second-First Millennia BC I 59 Kenneth Lymer, William Fitzhugh and Richard Kortum

\section{Zooarchaeological Analyses from the Roman and Medieval UK}

I4. Chasing Sylvia's Stag: Placing deer in the countryside of Roman Britain I74

Martyn G. Allen

I 5. Deer and Humans in South Wales during the Roman and Medieval Periods

Mark Maltby and Ellen Hambleton

I6. Making a Fast Buck in the Middle Ages: Evidence for poaching from Medieval Wakefield 200 Matilda Holmes

I7. 'Playing the stag' in Medieval Middlesex? A perforated antler from South Mimms Castle - parallels and possibilities 208 John Clark

\section{Landscapes}

I 8. Forest Law in the Landscape: Not the clearing of the woods, but the running of the deer? John Langton

I9. Parks and Designed Landscapes in Medieval Wales 23 I Spencer Gavin Smith

20. Preliminary Fieldwork and Analysis of Three Scottish Medieval 'Deer Parks' 240 Derek Hall, Kevin Malloy and Richard Oram 


\section{Post-Medieval Hunting in the UK}

2I. English Icons: The deer and the horse 248

Mandy de Belin

22. Femmes Fatale: Iconography and the courtly huntress

in the Later Middle Ages and Renaissance 257 Richard Almond

\section{Deer Management}

23. Supplemental Feeding and our Attitude towards Red Deer and Natural Mortality 270 Karoline T. Schmidt

24. Estimating the Relative Abundance of the Last Rhodian Fallow Deer, Dama dama dama, Greece, through Spotlight Counts: a pilot study 280 Marco Masseti, Anna M. De Marinis, Nikos Theodoridis and Konstantinia Papastergiou 


\title{
Deer and Humans in South Wales during the Roman and Medieval Periods
}

\author{
Mark Maltby and Ellen Hambleton
}

\section{Introduction}

Discussions of documentary and archaeological evidence pertaining to the history of the exploitation of deer in Britain have tended to focus on the evidence from Medieval England, from where most of the recent research has been carried out (e.g. Birrell 2006; Sykes 2006; Rotherham 2007). There have, however, been several recent papers that have incorporated documentary and topographical evidence from Wales and the Welsh Marches, mainly concerned with Medieval parks, forests and chases (e.g. Silvester 20IO; Langton 20II; Smith, this volume). To complement these discussions, this paper will consider zooarchaeological evidence for the exploitation of deer in south Wales from a number of important Roman and post-Roman excavations carried out during the last 30 years. The evidence relies heavily on recent, as yet unpublished, analyses of animal bones from Medieval and Early post-Medieval deposits at Laugharne Castle and the Roman town at Caerwent (Hambleton and Maltby 2004a; Hambleton and Maltby 2004b; Hambleton and Maltby 2009). The locations of these settlements and the other major sites discussed in the paper are shown in Figure 15.I. Raw data of species counts from all sites are provided in Table I5.I. Counts are restricted to those of the major domestic mammal foodproducing species (cattle (Bos sp.); sheep/goat (Ovis/Capra); pig (Sus sp.)) and the three species of deer that have been recorded in Wales during the periods involved. In most cases the counts are of the number of individual specimens (NISP). In a few cases the counts have been derived from selected bone counts. Although both methods tend to bias counts towards large mammals, the results from the two methods are usually compatible (Maltby 20I0).

\section{Deer remains from Roman period sites}

Archaeological evidence for the exploitation of deer is limited to a handful of sites in southern Wales, although large assemblages have been analysed at the 


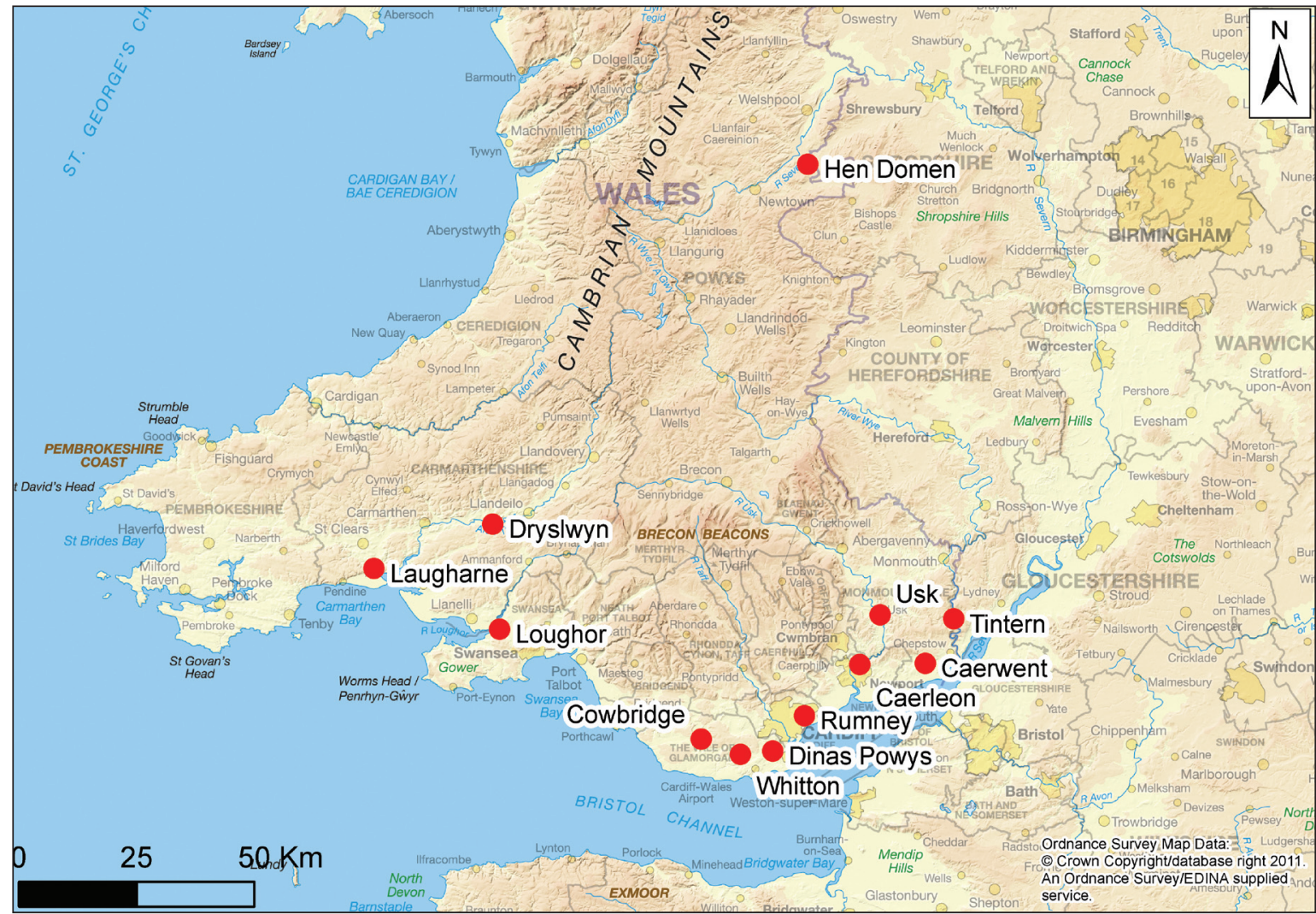

town of Caerwent, the fortress at Caerleon and the auxiliary fort at Loughor. The largest assemblage in this survey was obtained from the area around the Basilica at the civitas capital at Caerwent, Gwent (Hambleton and Maltby 2004b). Red deer (Cervus elaphus) provided only o.3 percent of the selected mammal assemblage (Table I5.I). This is typical of Romano-British urban assemblages, in which red deer elements provide less than $\mathrm{I} \%$ of the total cattle, sheep/goat, pig and deer counts (Maltby 20IO). There was no marked chronological variation in their relative abundance, although they were marginally better represented in late Roman deposits (Hambleton and Maltby 2004b).

There was no significant bias towards elements from particular parts of the body, although vertebrae were poorly represented. Notably, there was no bias towards hindlimb elements. Indeed forelimb bones (apart from the metacarpal) were better represented. At least five scapulae were represented (Table 15.2).

Butchery marks on red deer bones included superficial chop marks on the medial aspect of a proximal radius and heavy axial blade marks along the edges of the proximal articulation of a tibia. Both are characteristic of marks commonly inflicted on cattle upper limb bones on Roman urban settlements (Maltby 2007; Maltby 2010), indicating that some deer were acquired and processed by specialist butchers. Three scapulae had been chopped transversely where the shoulder had been segmented from the upper forelimb. It is feasible

FIGURE I5.I. Map of south Wales showing principal sites discussed in this survey. 


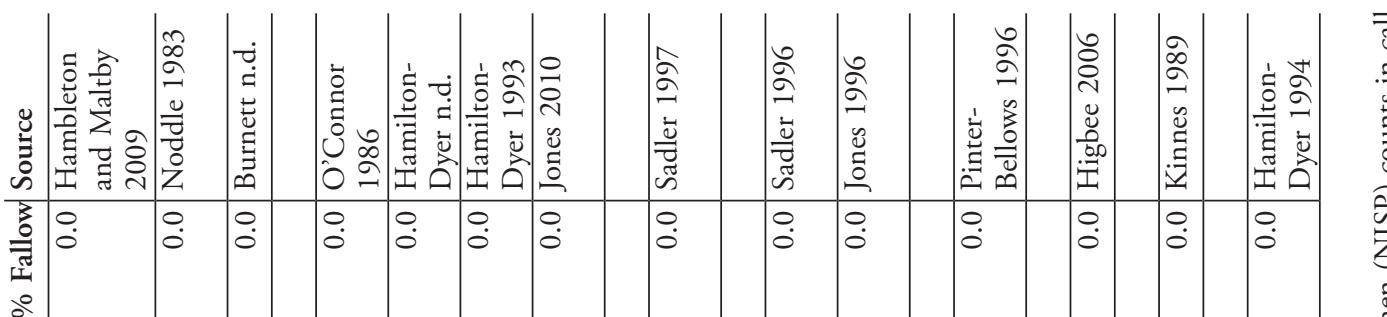

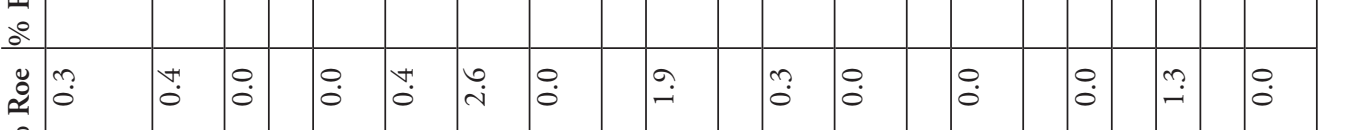

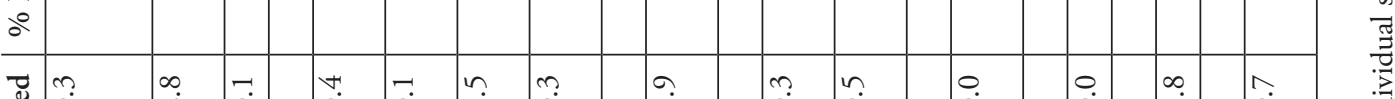

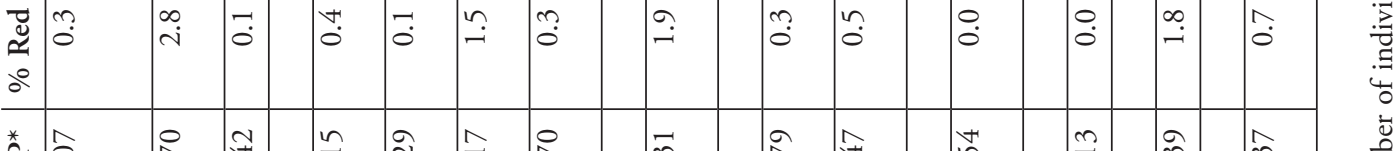

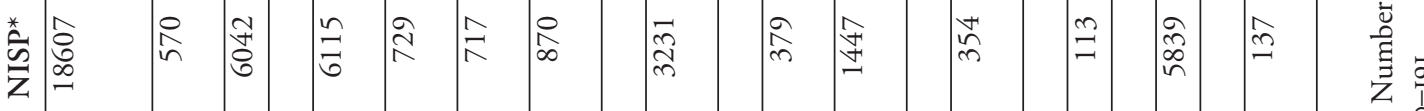

毫

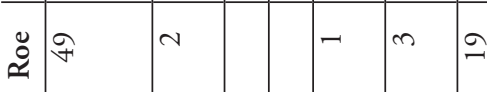

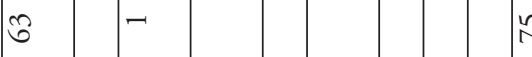

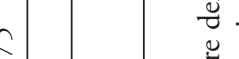

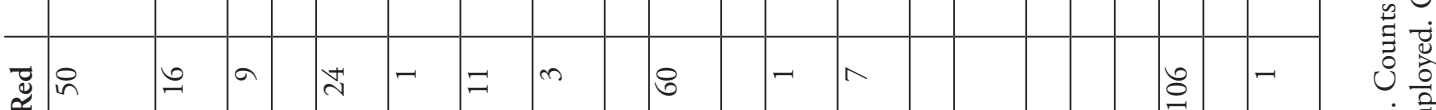

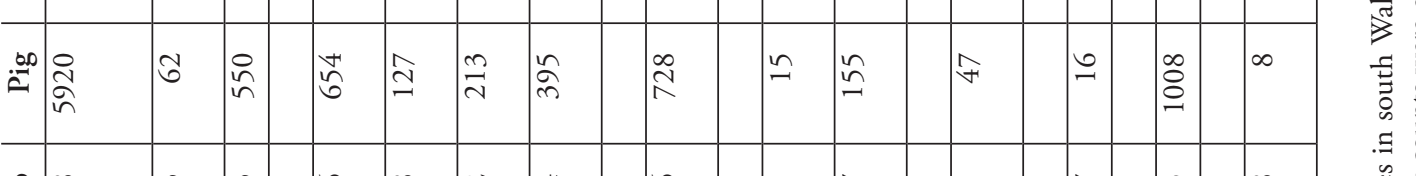

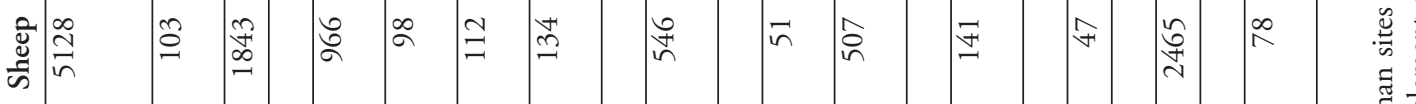

苛言

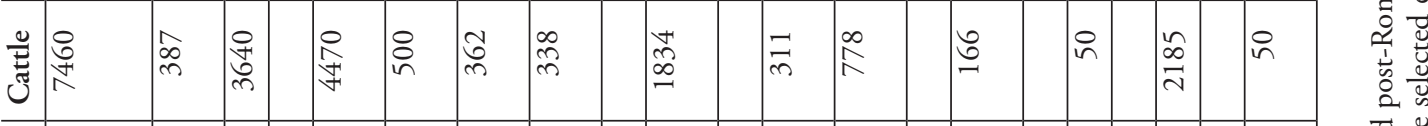

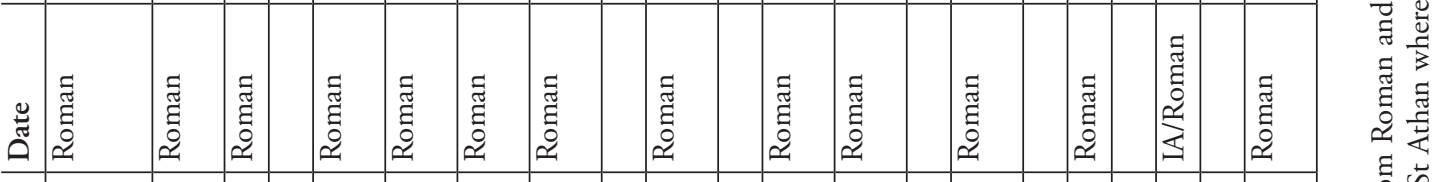

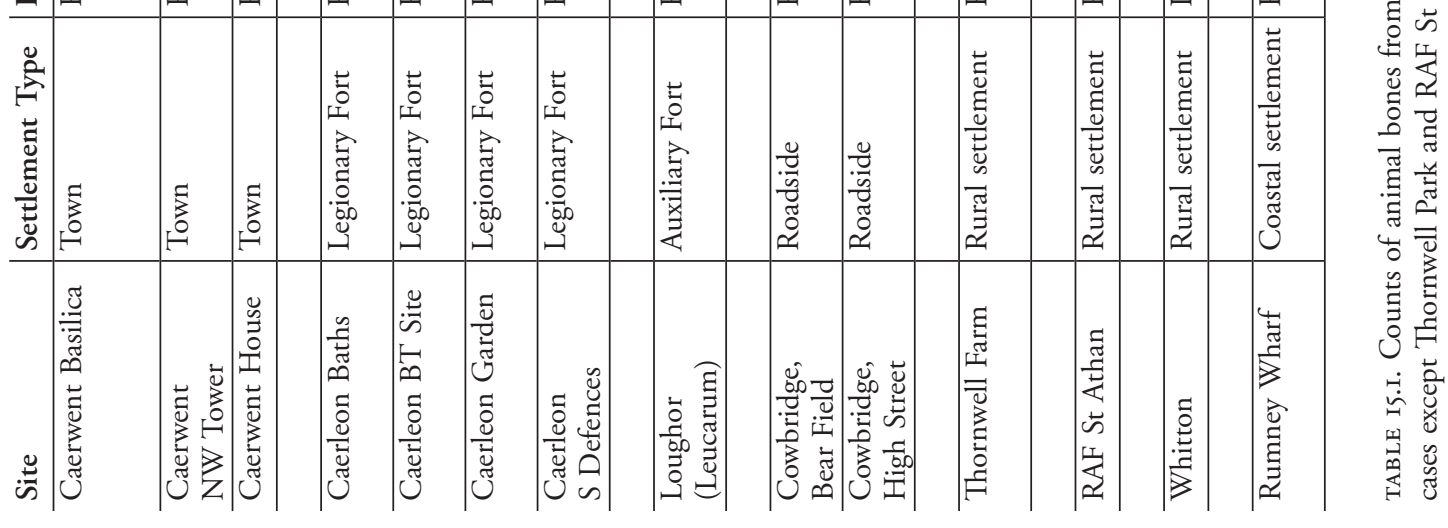




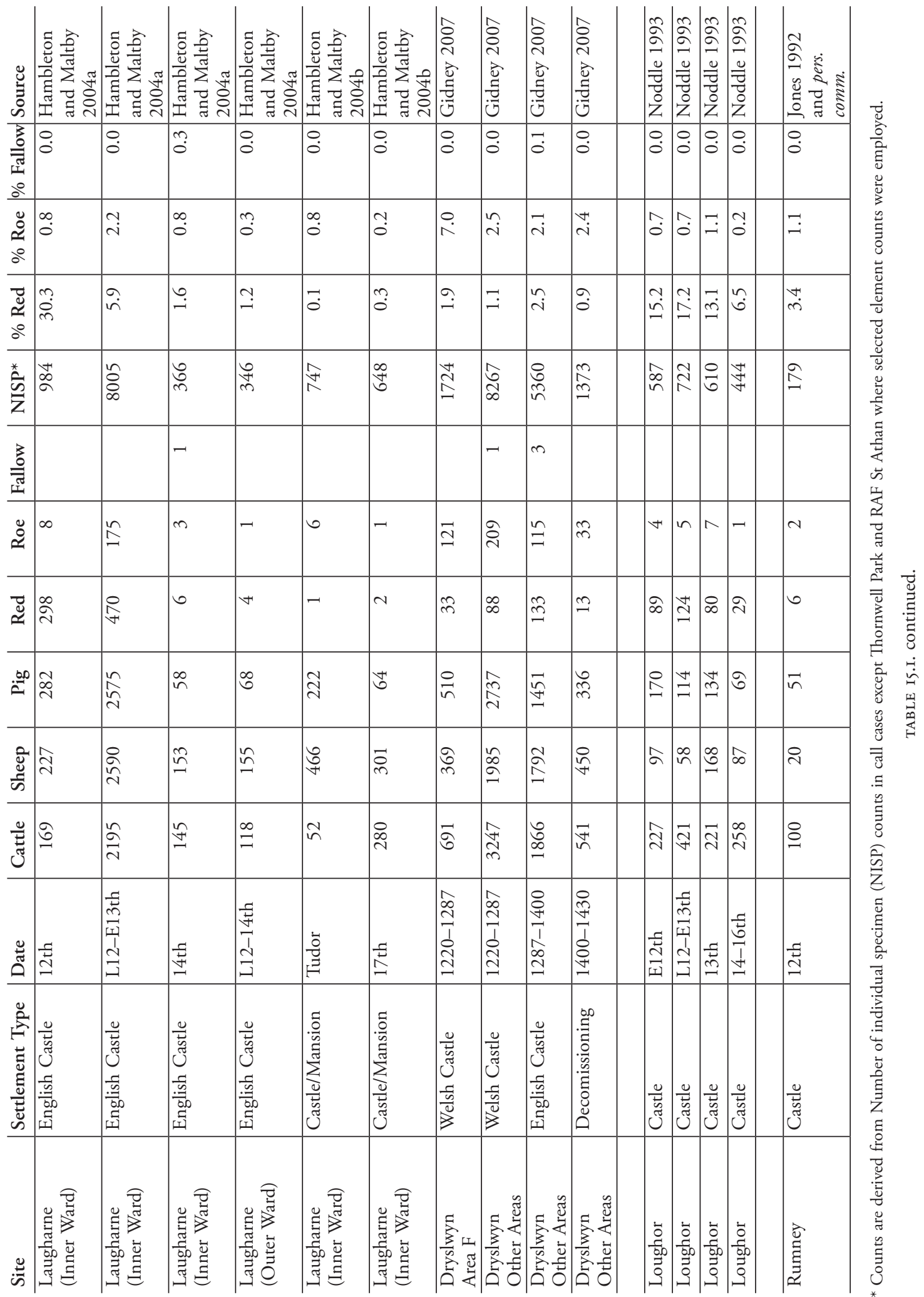




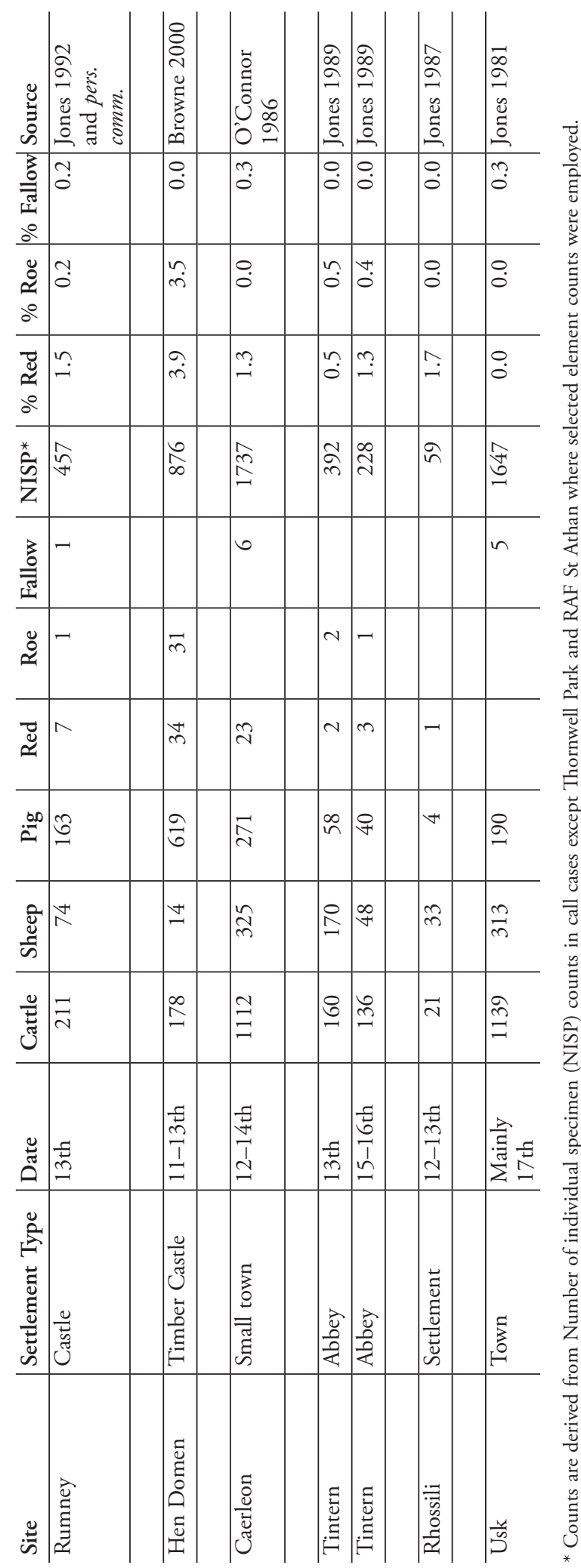

that these were shoulder joints preserved by smoking and/or salting, again a practice that has parallels in Roman cattle butchery (Dobney 200I; Maltby 2007).

Roe deer (Capreolus capreolus) also contributed 0.3 percent of the identified mammal assemblage at the Caerwent Basilica site (Table I5.I). Their rarity is typical of most Romano-British urban assemblages (Maltby 20IO). There was a bias towards larger, denser bones with no records of tarsals, phalanges, ribs or vertebrae. Forelimbs were slightly better represented than hindlimbs. At least six mandibles and humeri were represented (Table I5.2).

A courtyard house in the north-west corner of Caerwent has also produced a substantial assemblage. Red deer were very poorly represented and no roe deer remains were identified (Burnett nd). A much smaller assemblage was obtained from excavations near the town wall of Caerwent (Noddle 1983). This produced an unusually high percentage of red deer ( 2.8 percent).

Four sites from the legionary fortress at Caerleon, $\mathrm{I} 3 \mathrm{~km}$ to the west of Caerwent, are included in this survey (Table I5.I). Three assemblages contained very small percentages of red and roe deer (both species under 0.5 percent). The fourth, from the Museum Garden site, produced very high percentages of roe (2.6 percent) and red deer (I.5 percent) (Hamilton-Dyer 1993). These bones were largely derived from a well, which also included significant numbers of wild boar (Sus scrofa) and crane (Grus sp.) bones, and other luxury foods such as grapes and figs. The well had partly been filled with kitchen waste from the residence of a high-ranking officer (Zienkiewicz 1993, 77). Excluding this deposit, the percentages of red deer ( 0.6 percent) and roe deer (0.5 percent) are at levels more typical of other assemblages from the fortress (Hamilton-Dyer 1993). 


\begin{tabular}{|c|c|c|c|c|c|c|c|c|c|c|}
\hline & \multicolumn{4}{|c|}{ Caerwent } & \multicolumn{2}{|c|}{ Leucarum } & \multicolumn{4}{|c|}{ Laugharne Castle } \\
\hline & \multicolumn{4}{|c|}{$\begin{array}{l}\text { Basilica Site } \\
\text { (Hambleton and Maltby 2009) }\end{array}$} & \multicolumn{2}{|c|}{ (Sadler 2007) } & \multicolumn{4}{|c|}{$\begin{array}{l}\text { Medieval deposits from Inner Ward } \\
\text { (Hambleton and Maltby 2004a) }\end{array}$} \\
\hline & \multicolumn{2}{|c|}{ Red } & \multicolumn{2}{|c|}{ Roe } & Red & Roe & \multicolumn{2}{|c|}{ Red } & \multicolumn{2}{|c|}{ Roe } \\
\hline Element & NISP & $M N E$ & NISP & $M N E$ & NISP & NISP & NISP & $M N E$ & NISP & $M N E$ \\
\hline Antler & 4 & 3 & I & I & I7 & 5 & 20 & nc & 5 & nc \\
\hline Maxilla & I & I & I & I & I & & I I & 5 & 4 & 4 \\
\hline Skull frag & & & I & I & & & I I & 3 & & \\
\hline Mandible & 3 & 3 & 6 & 6 & 2 & 4 & 7 & 4 & 7 & 6 \\
\hline Teeth & 5 & $\mathrm{nc}$ & & & 2 & I & I 8 & nc & 9 & nc \\
\hline Scapula & 6 & 5 & I & I & 3 & I & 5 & 4 & 7 & 7 \\
\hline Humerus & I & I & 7 & 6 & 5 & 7 & 8 & 6 & 9 & 7 \\
\hline Radius & 6 & 4 & 4 & 4 & 2 & 9 & IO & 6 & 9 & 8 \\
\hline Ulna & 4 & 3 & 4 & 3 & $\mathrm{I}$ & 6 & 6 & 4 & 2 & 2 \\
\hline Pelvis & 2 & $\mathrm{I}$ & 5 & 5 & 3 & 3 & 42 & I9 & 9 & 9 \\
\hline Femur & 3 & I & I & I & 5 & 3 & I I 2 & 39 & 4 & 3 \\
\hline Patella & & & & & & & $\mathrm{I}$ & $\mathrm{I}$ & & \\
\hline Tibia & 3 & 2 & 6 & 4 & $\mathrm{I}$ & 8 & 125 & $6 \mathrm{I}$ & $2 \mathrm{I}$ & I 3 \\
\hline Carpals & & & & & 2 & & I & $\mathrm{I}$ & & \\
\hline Astragalus & & & & & $\mathrm{I}$ & 2 & 40 & 39 & & \\
\hline Calcaneus & & & & & 2 & & 45 & 43 & 6 & 6 \\
\hline Cuboid & & & & & & & 7 & 7 & & \\
\hline Tarsals & & & & & & & 9 & 9 & & \\
\hline Metacarpal & & & 8 & 5 & 2 & 3 & 2 & 2 & 5 & 4 \\
\hline Metatarsal & 4 & 2 & 4 & 2 & 3 & 8 & 3 & 3 & 19 & 8 \\
\hline Metapodial & & & & & & & & & I & nc \\
\hline Phalanx 1 & 3 & $\mathrm{I}$ & & & 2 & 3 & 2 & $\mathrm{I}$ & I & $\mathrm{I}$ \\
\hline Phalanx 2 & 4 & I & & & $\mathrm{I}$ & & $\mathrm{I}$ & $\mathrm{I}$ & & \\
\hline Phalanx 3 & & & & & & & I & I & & \\
\hline Atlas & I & I & & & & & & & I & I \\
\hline Axis & & & & & & & $\mathrm{I}$ & $\mathrm{I}$ & 2 & 2 \\
\hline Lumbar V & & & & & 5 & & & & & \\
\hline Sacral V & & & & & & & I & I & & \\
\hline Total & 50 & & 49 & & 60 & 63 & 489 & & I 21 & \\
\hline
\end{tabular}

NISP = number of individual specimens; $\mathrm{MNE}=$ minimum number of element; $\mathrm{nc}=\mathrm{MNE}$ not calculated

Both red and roe deer were also (by Romano-British standards) well represented at another military site, the auxiliary fort of Leucarum situated at Loughor, on the outskirts of Swansea. They each provided I.9 percent of the assemblage (Sadler 1997), although the red deer numbers were slightly inflated by a high antler count and possibly an associated group of five lumbar vertebrae (Table I5.2).

Assemblages from the roadside settlement of Cowbridge, South Glamorgan, had low numbers of red and roe deer (Jones 1996; Sadler 1996) (Table 15.I). Only one fragment of red deer was found at Rumney Wharf (Hamilton-Dyer 1994) and two small assemblages from rural settlements at Thornwell Farm
TABLE 2. Deer elements in assemblages recorded in detail. NISP = number of individual specimens; $\mathrm{MNE}=$ minimum number of element; nc $=$ MNE not calculated. Caerwent $=$ Basilica Site (Hambleton and Maltby 2009); Leucarum (Sadler 2007); LC = Laugharne Castle Medieval deposits from Inner Ward (Hambleton and Maltby 2004a). 
(Gwent) and RAF St Athan (Vale of Glamorgan) included no deer remains at all (Pinter-Bellows 1996; Higbee 2006). The large assemblage from Whitton (Vale of Glamorgan) produced higher percentages of both red (I.8 percent) and roe deer (I.3 percent) (Kinnes 1989). Unfortunately the assemblage from this high status Late Iron Age and Romano-British settlement was not subdivided by period and no further details of the deer assemblages were published.

Information about mortality profiles of the deer found on Roman sites is limited, because of small sample sizes and lack of discussion in some reports. However, the great majority of the red and roe deer from Caerwent, Caerleon and Leucarum were adult animals.

\section{Deer remains from post-Roman sites}

Evidence for the hunting of deer is very poorly documented in the archaeological record of the period between the fifth and eleventh century. The hillfort of Dinas Powys, Vale of Glamorgan produced a large bone assemblage. Unfortunately, only part of it was retained. The assemblage analysed from this high status site was dominated by pig, followed by cattle and sheep/goat. Only fifteen elements of deer were identified but not to species level (Haglund-Calley and Cornwall 1963). Gilchrist's (1988) reanalysis of the bones did not consider wild species in the published discussion. No other Dark Age sites from south Wales have produced a faunal sample worthy of detailed analysis.

Nearly all of the few large animal bone assemblages from the period after Io66 have been obtained from castles. The two main assemblages that have been examined in detail are located at Laugharne and Dryslwyn, Dyfed (Figure 15.I).

Laugharne Castle was occupied for most of the Medieval period by AngloNorman families. Red deer bones were particularly abundant (30.3 percent) in the earliest twelfth century deposits from the Inner Ward outnumbering all the domestic species in the assemblage. They were also found commonly ( 5.9 percent) in the substantial assemblages obtained from late twelfth and early thirteenth century deposits. They became less abundant in Late Medieval features (I.6 percent) and virtually disappeared in the post-Medieval deposits (O.I-O.3 percent). There were intra-site variations, however. In the Outer Ward, red deer fragments were relatively uncommon (I.2 percent) throughout the Medieval deposits (Table I5.I) (Hambleton and Maltby 2004a; Hambleton and Maltby 2004b).

The high percentages of red deer in the earlier deposits, were remarkable considering only a small range of their bones were commonly deposited in the Inner Ward. The assemblages were dominated by bones of the haunches and adjacent areas (femur, tibia, pelvis, astragalus and calcaneus). Metatarsals, phalanges and all forelimb bones were very poorly represented. Cranial elements consisted mainly of worked antler (Table 15.2). Disarticulation of the feet was evidenced by knife cuts and, less commonly, by chop marks on the astragalus, calcaneus and distal tibia. Chop marks on the pelvis and the proximal femur indicate segmentation of the carcass around the hip joint. 
Roe deer bones were less well represented than red deer in the Medieval deposits, but were nevertheless found in larger proportions than in most of the Roman assemblages. There was a much more even representation of forelimb and hindlimb elements, but cranial elements were under-represented. Only a single pelvis from a fourteenth century context was identified as fallow deer (Dama dama).

The largest faunal assemblage from a Medieval site in south Wales has been obtained from Dryslwyn Castle. This is situated about $23 \mathrm{~km}$ to the north-east of Laugharne (Figure I5.I). In contrast to Laugharne, Dryslwyn was a Welsh castle from its foundation in the I220s until its capture by the English in I287. Thereafter, a constable held the castle on behalf of the English king or lords (Gidney and Caple 2007). Red deer percentages from thirteenth and fourteenth century samples were slightly lower (I.I-2.5 percent) than contemporary assemblages from Laugharne (Gidney 2007). Indeed, roe deer outnumbered red deer bones at Dryslwyn in most periods, particularly in the earliest phase (7.0 percent). Fallow deer identifications were restricted to four bones, three from the initial phase of English occupation in the fourteenth century (Table I5.I). No detailed information about butchery and body part representation has been published, although Gidney $(2007,307)$ did note that red deer hindlimbs were better represented than the forelimbs.

Another Anglo-Norman foundation at Loughor Castle, $30 \mathrm{~km}$ east of Laugharne, was located within the boundaries of the Roman auxiliary fort of Leucarum discussed above. The assemblage of over 2,00o bones produced very high percentages of red deer throughout its twelfth to thirteenth century phases (I3.I-I7.2 percent). Although percentages decreased in the fourteenth to sixteenth century deposits (6.5 percent), red deer bones were substantially more abundant than at Laugharne and Dryslwyn. Unfortunately, no information about body part representation was published. Roe deer were present in smaller but consistent numbers (0.2-I.I precent) but no fallow deer bones were identified (Noddle 1993).

Excavations at the Anglo-Norman Rumney Castle, South Glamorgan, produced a small twelfth century assemblage dominated by cattle, but with a relatively high percentage of red deer (3.4 percent). Roe deer was also present (I.I percent). A larger sample from thirteenth century levels produced lower percentages of red deer (I.5 percent) and single occurrences of both roe and fallow deer (Jones 1992 and pers. comm.).

Further north-east, the timber castle at Hen Domen, Montgomery, produced an assemblage mainly derived from one pit from the bailey. This was dominated by pig. Both red (3.9 percent) and roe deer (3.5 percent) were well represented. The limited evidence for body part representation showed a bias towards the hindlimb (Browne 2000, I3I). No bones of fallow deer were identified.

Unfortunately, assemblages from non-castle sites in southern Wales are extremely scarce. Medieval deposits from Caerleon have produced the largest sample of over I,700 specimens (O'Connor 1986). Red deer were found in 
smaller amounts (I.3 percent) than in nearly all the castle samples and no roe deer bones were identified at all. Perhaps surprisingly, several fallow deer bones were present in demolition layers dated to the thirteenth century, a period when they were not recorded in any of the castles discussed above.

A fairly small sample was obtained from Tintern Abbey. Modest quantities of red deer (0.5-I.3 percent) and roe deer bones (0.4-0.5 percent) were recovered from both Medieval and Early post-Medieval deposits but no fallow deer bones were identified (Jones 1989). The rural settlement at Rhossili, West Glamorgan, produced a very small faunal sample that included a single bone of red deer (Jones 1987).

Apart from Laugharne, the only post-Medieval assemblage of significant size has come from the town of Usk, Gwent. Most of the assemblage was of seventeenth century date and was dominated by cattle, whereas deer bones were rare. The only species identified was fallow (0.3 percent) (Jones 198I).

Discussions related to post-Roman mortality patterns of deer have been limited. It seems, however, that the majority of venison consumed belonged to adult animals of all three species. At Laugharne, 85 percent of the latestfusing epiphyses of red deer limb bones had fused, indicating the focus on the acquisition of fully-grown animals. Adults also dominated the smaller roe deer assemblage (Hambleton and Maltby 2004a). Sub-adult roe deer were quite common in the Dryslwyn assemblage (Gidney 2007, 307).

\section{Discussion}

The survey has confirmed that only two species of deer were definitely present in southern Wales during the Roman period. The absence of fallow deer is unsurprising, as the presence of this imported species has hitherto only been authenticated on a small number of high status sites in southern England (Sykes et al. 20II). Although the percentages of red and roe deer are generally low on the Welsh sites, there are some indications that they were more likely to be found on sites associated with people of high status. The clearest example is the presence of both species amongst other 'luxury' foods in kitchen waste associated with high-ranking officers at the legionary fortress of Caerleon. The deposition of these together within a disused well suggests that they were consumed at a special banquet hosted by the officer involved (Hamilton-Dyer 1993, I36). If it was derived from one meal, it included the meat from at least four cranes, a wild boar, two roe deer and possibly two red deer. The remaining assemblages from this site and others in Caerleon were much less diverse with deer bones present in only small quantities.

Variations in dietary breadth within Roman military sites have also been observed at the fort of South Shields on Hadrian's Wall. Here, assemblages associated with the commandant's residence produced a much broader range of species, including red and roe deer, than in deposits associated with the barrack blocks (Stokes 2000). The high percentages of deer remains at Leucarum may 
also reflect the fact that most of the bones were recovered from the vicinity of the praetorium, and perhaps also associated with the garrison commanders (Sadler 1997).

Significantly higher percentages of red deer remains were found in the assemblage from near the north-west defences in Caerwent than from elsewhere in the town, which may indicate the presence of a high status residence nearby. There are indications from the butchery evidence that some of the red deer in Caerwent were acquired and processed by the urban specialist butchers.

The presence of large quantities of deer on high status Medieval sites in Wales is to be expected given their prevalence at castles and manors in England (Sykes 2006). The main difference in comparison with southern England is that fallow deer were present, if at all, only in small numbers. The absence of fallow from twelfth century deposits is understandable, as their frequency tended to increase from the mid-twelfth century onwards as deer parks stocked with fallow became established. However, they are also virtually absent from later Medieval deposits from Laugharne, Dryslwyn, Loughor and Rumney. They were found as infrequently as in urban deposits at Caerleon. There is therefore only tentative evidence that fallow deer were introduced to Wales during this period. One could account for the presence of the few fallow deer as imports of salted venison (Birrell 2006).

There may well have been sufficient numbers of red and roe deer in the forests and chases of south Wales to meet the needs of the Welsh or Anglo-Norman gentry. The percentages of deer on the castle sites tended to decrease during the Medieval period (Table I5.I), which might reflect pressures on diminishing resources. However, percentages also vary according to areas within the castles excavated. At Laugharne in particular, much higher percentages of deer remains were associated with the kitchen waste from the Inner Ward than from peripheral parts of the castle. High percentages of deer in the earliest phases of these castles may reflect the desire of the elite to demonstrate their wealth, legitimise their status and strengthen their position in the area by commonly hosting feasts.

The relative abundance of red and roe deer varies between Medieval sites. At the Anglo-Norman Castles of Laugharne, Loughor and Rumney, red deer outnumbered roe. The opposite was the case in the period of Welsh occupation at Dryslwyn. Whether this reflects variations in local availability is unclear, but it is interesting to note that red deer outnumbered roe at Dryslwyn during the initial phase of English occupation. At this time, documentary evidence indicates that provisioning of the castle garrison relied more on purchases from market towns (Gidney and Caple 2007). Isotopic analysis of pigs has raised the possibility that they may have been procured from another source at this time (Millard et al. 20II). It is feasible that at least some of the red deer may have been acquired from outside the local area.

Only at Laugharne (Table 15.2) has it been possible to demonstrate the expected dominance of haunches of red deer that are such a prominent feature 
of assemblages of red and fallow deer from high status sites in England (Sykes 2006; Thomas 2007). It is likely that similar strict rules regarding the hunting of large deer and the distribution of their body parts were in operation in these Anglo-Norman castles. The same may have been true during the Welsh occupation at Dryslwyn but details are lacking.

This brief survey has demonstrated both similarities and differences regarding the acquisition and consumption of venison between south Wales and southern England, particularly in the Medieval period. It provides the basis for more detailed comparisons with future assemblages. Re-examination of some of the analysed assemblages would provide further information about element representation, butchery practices and isotopic signatures. There is also potential for a comprehensive survey of the stature of red deer and possible changes related to variations and changes in habitat in the region.

\section{Acknowledgements}

We would like to acknowledge the kind assistance of Gill Jones and Sheila Hamilton-Dyer for additional information that was unavailable from their published works, and for pointing us towards several reports that we were unaware of. Astrid Caseldine also kindly supplied references to other published works. Thanks too to Richard Brewer for allowing us to use material from excavations in Caerwent in advance of publication. Mark Dover created Figure I5.I. The paper is dedicated to the memory of Richard Avent, who provided us with the opportunity to study the material from his excavations at Laugharne Castle.

\section{References}

Birrell, J. (2006) 'Procuring, preparing and serving venison in late Medieval England', in Food in Medieval England, eds C. Woolgar, D. Serjeantson and T. Waldron, OUP, Oxford, I76-I88.

Browne, S. (2000) 'The animal bones', in Hen Domen, Montgomery: a Timber Castle on the English-Welsh Border: a Final Report, eds R. Higham and P. Barker, University of Exeter Press, Exeter, I26-I34.

Burnett, D. (n.d.) 'The animal bones from excavations of a courtyard house in the NW corner of Caerwent', Consultancy Report for National Museum of Wales.

Dobney, K. (200I) 'A place at the table: the role of vertebrate zooarchaeology within a Roman research agenda', in Britons and Romans: advancing an Archaeological agenda, eds S. James and M. Millett, CBA Research Report, London, 36-45.

Gidney, L. (2007) 'Animal and bird bones', in Excavations at Dryslwyn Castle 1980-95, ed. C. Caple, Society for Medieval Archaeology Monograph, Leeds, 295-3I4.

Gidney, L. and Caple, C. (2007) 'Food production and consumption in Wales: 13th to I5th centuries', in Excavations at Dryslwyn Castle 1980-95, ed. C. Caple, Society for Medieval Archaeology Monograph, Leeds, 283-295.

Gilchrist, R. (1988) 'A reappraisal of Dinas Powys: local exchange and specialized livestock production in 5th- to 7th-century Wales', Medieval Archaeology 32, 50-62. 
Haglund-Calley, L. and Cornwall, I. (1963) 'Report on the Dinas Powys animal bones', in Dinas Powys: An Iron Age, Dark Age, and Medieval Settlement in Glamorgan, ed. L. Alcock, University of Wales Press, Cardiff, I92-194.

Hambleton, E. and Maltby, M. (2004a) 'Animal Bones from Medieval Contexts at Laugharne Castle, Dyfed, Wales', Consultancy Report for CADW, Bournemouth University.

Hambleton, E. and Maltby, M. (2004b) 'Animal Bones from Post-medieval Contexts at Laugharne Castle, Dyfed, Wales', Consultancy Report for CADW, Bournemouth University.

Hambleton, E. and Maltby, M. (2009) 'Animal Bones from Caerwent Forum-Basilica, Wales', Consultancy Report for National Museum of Wales, Bournemouth University.

Hamilton-Dyer, S. (1993) 'The animal bones', in ed. V. Zienkiewicz, 'Excavations in the Scamnum Tribunorum at Caerleon', Britannia 24, I32-136.

Hamilton-Dyer, S. (1994) 'The animal bone', in ed. M. Fulford, J. Allen and S. Rippon, 'The settlement and drainage of the Wentlooge Level, Gwent: excavation and survey at Rumney Great Wharf, 1992', Britannia 25, 197-200.

Hamilton-Dyer, S. (n.d.) 'The animals bones from excavations at the British Telecom site, Caerleon'. Consultancy Report.

Higbee, L. (2006) 'Animal bone', in ed. A. Barber, S. Cox and A. Hancocks, 'Vale of Glamorgan: evaluation and excavation 2002-3', Archaeologia Cambrensis I55, 9I-94.

Jones, G, (198I) 'The animal bone', in ed. V. Metcalfe Dickenson, 'Excavations at Old Market Street, Usk', The Monmouthshire Antiquary 4, 33-35.

Jones, G. (1987) 'Animal bones', in ed. H. Owen John, 'Excavations at the sand covered Medieval settlement at Rhossili, West Glamorgan', The Bulletin of the Board of Celtic Studies 34, 268-269.

Jones, G. (1989) 'The animal bones' in ed. P. Courtney, 'Excavations in the outer precinct of Tintern Abbey', Medieval Archaeology, 33, I38-I4I.

Jones, G. (1992) 'The animal bone' in. ed K. Lightfoot. 'Rumney Castle, a ringwork and manorial centre in South Glamorgan', Medieval Archaeology 36, I5I-155.

Jones, G. (1996) 'The animal bones from 75 High Street', in Excavations at Cowbridge, South Glamorgan, 1977-88, eds J. Parkhouse and E. Evans, BAR British Series 245, Archaeopress, Oxford, 226-232.

Jones, G. (2010) 'Animal bones', in The Excavation of the Southern Defences of the Caerleon Legionary Fortress 1982, eds H. Mason, P. Macdonald and H. Cool, Archaeology Data Service, York (doi:I0.5284/Iooor6I).

Kinnes. I. (1989) 'The animal bones', in Whitton: an Iron Age and Roman Farmstead in South Glamorgan, eds M. Jarrett and S. Wrathmell, University of Wales Press, Cardiff, 232.

Langton, J. (20II) 'Forest and chases in Wales and the Welsh Marches: an exploration of their origins and characteristics', Journal of Historical Geography, 37, 263-272.

Maltby, M. (2007) 'Chop and change: specialist cattle carcass processing in Roman Britain', in TRAC 2006: Proceedings of the I6th Annual Theoretical Roman Archaeology Conference, Cambridge 2006, eds B. Croxford, N. Ray, R. Roth and N. White, Oxbow, Oxford, 59-76.

Maltby. M. (20I0) Feeding a Roman Town: Environmental Evidence from Excavations in Winchester, 1972-1985, Winchester Museums Service, Winchester.

Millard, A., Jimenez-Cano, N., Lebrasseur, O. and Saki, Y. (20II) 'Isotopic investigation of animal husbandry in the Welsh and English periods at Dryslwyn Castle, 
Camarthenshire, Wales', International Journal of Osteoarchaeology DOI:Io.Ioo2/ oa.I292

Noddle, B. (1983) 'The animal bones', in ed. P. Casey, 'Caerwent (Venta Silarum): the excavations of the north-west corner tower and analysis of the structural sequence of the defences', Archaeologia Cambrensis 132, 63-69.

Noddle, B. (1993) 'The mammal bones', in J. M. Lewis, 'Excavations at Loughor Castle, West Glamorgan 1969-73', Archaeologia Cambrensis I42, I59-169.

O'Connor, T. (1986) 'The animal bones', in The Legionary Fortress Baths at Caerleon: Volume II. The Finds, eds J. D. Zienkiewicz, National Museum of Wales/CADW, Cardiff, 225-248.

Pinter-Bellows, S. (1996) 'The animal bone', in The Excavation of a Late Prehistoric and Romano-British Settlement at Thornwell Farm, Chepstow, Gwent, 1992, ed. G. Hughes, BAR British Series 244, Archaeopress, Oxford, 8I-84.

Rotherham, I. (2007) 'The ecology and economics of medieval deer parks', Landscape Archaeology and Ecology 6, 86-IO2.

Sadler, P. (1996) 'The animal bones from Bear Field', in Excavations at Cowbridge, South Glamorgan, 1977-88, eds J. Parkhouse and E. Evans, BAR British Series 245, Archaeopress, Oxford, 224-227.

Sadler, P. (1997) 'Faunal remains', in Leucarum: excavations at the Roman auxiliary fort at Loughor, West Glamorgan 1982-84 and 1987-88, eds A. Marvell and H. Owen-John, Britannia Monograph, London, 396-409.

Silvester, R. (2010) 'Historical concept to physical reality: forests in the landscape of the Welsh borderlands', in Forests and Chases of Medieval England and Wales, c.10oo to I50o, eds J. Langton and G. Jones, St John's College, Oxford, I63-178.

Stokes, P. (2000) 'A cut above the rest?' Officers and men at South Shields Roman fort', in Animal Bones, Human Societies, ed. P. Rowley-Conwy, Oxbow, Oxford, I46-I5I.

Sykes, N. (2006) 'The impact of the Normans on hunting practices in Britain', in Food in Medieval England, eds C. Woolgar, D. Serjeantson and T. Waldron, Oxford University Press, Oxford, I62-175.

Sykes, N. (2010) 'Deer, land, knives and halls: social change in Early Medieval England', Antiquaries Journal 90, 175-191.

Sykes, N., Baker, K., Carden, R. F., Higham, T., Hoelzel, R. and Stevens, R. (20II) 'New evidence for the establishment and management of European fallow deer (Dama dama dama) in Roman Britain', Journal of Archaeological Science 38, I56-165.

Thomas, R. (2007) 'Maintaining social boundaries through the consumption of food in medieval England', in The Archaeology of Food and Identity, ed. K. Twiss, Southern Illinois University Centre for Archaeological Investigations Occasional Paper, Carbondale, I30-I5I.

Zienkiewicz, V. (1993) 'Excavations in the Scamnum Tribunorum at Caerleon', Britannia 24, 27-I4O. 